\title{
Interview
}

\section{How digital brands can succeed and thrive in the engaged era - An interview with Igor Beuker, founder of Grupo LaComunidad}

\author{
Igor Beuker \\ had been CMO at such listed companies as Scoot, TeliaSonera and mmO2. In 2003, he founded digital marketing agency \\ LaComunidad. In 2004, he founded online video metrics company ViralTracker, and in 2007 social media marketing agency \\ SocialMedia8 and ViralBlog. In 2008, marketing communications world leader WPP acquired his Grupo LaComunidad. Igor was \\ the chairman of the Interactive Advertising Bureau (IAB) from 2002 until 2006. He is a listed top-10 trend watcher at Speakers \\ Academy and he frequently shakes up national and international marketing events with his spicy vision. He gains new insights \\ as a jury member at Spin Awards, Webby Awards and AMMA Awards. Igor loves to read, speak and write about digital \\ brand programming, viral and social media marketing, e-commerce, consumer contact improvement, and communities. As an \\ entrepreneur he is a shareholder and board member at several start-ups.
}

\begin{abstract}
Innovative brand engagement architectures, smart communication and messaging platforms, CRM-driven systems, technologies and infrastructures are now part of marketing. Michael Moon interviews Igor Beucker of Grupo LaComunidad on how a new type of digital agency addresses these changes, including a Nike case study. Journal of Digital Asset Management (2009) 5, 375-382. doi:10.1057/dam.2009.28
\end{abstract}

Keywords: digital; social; marketing; innovate; invent; interact

Correspondence: Igor Beuker La Comunidad, Karperstraat 10, 1075 KZ7 Amsterdam, the Netherlands

E-mail: igor@ lacomunidad.nl com
MM: We're here with Igor Beuker, founder of Grupo LaComunidad, based in Amsterdam the Netherlands. Igor, if you would start off with a little of your personal background and career highlights.

IB: I had a short career as a professional football player. That's how I stepped into a sports marketing agency in 1991. In 1994 I switched to a multi-channel broadcasting company, where I fell in love with the Internet. In 1997 I started at local search company Scoot. Until 2003 I worked as marketing director at two listed telecom companies: TeliaSonera and $\mathrm{O} 2$ in the UK.

End of 2003, I decided to leave my job as a consumer marketing manager, and founded digital marketing agency LaComunidad. We felt there was a need for a powerhouse agency, one that dared to go beyond campaigns and was able to unleash the power of digital marketing to transform business models and brands.
In 2004, we envisioned the Internet moving into a platform for audio/video entertainment, music, gaming and entertainment - a fullmotion platform. We knew that all brands had embraced the power of TV commercials. And LaComunidad had already created a lot of successful branded content and viral commercials. To prove the impact and ROI of viral and video content on brands, we developed and launched an independent third video-tracking company called ViralTracker. ViralTracker proofs the reach, impact, creativity and return on investment of online videos, trailers and widgets of over 100 brands worldwide.

In 2007, we tapped deeper into the space of social media marketing. In 2007, I founded social media marketing agency SocialMedia8. The agency is engaging consumers and mediating between consumers and brands within the social media landscape. SocialMedia8, based in Amsterdam, rapidly opened in London, 
Madrid and Milan as well. In 2008, WPP (NASDAQ: WPPGY) - a world leader in marketing communications - acquired 75 per cent of our Grupo LaComunidad.

MM: Igor, would you give us an example or two of the client and the kind of social media monitoring or other sorts of services that you deliver?

IB: I will mention Nike. Through traditional advertising they reach millions of consumers already. It's also almost an Apple-like brand. They have great advertising agencies to do so, through broadcast media.

For Nike we identified several groups of social influencers and invited them to participate in one of the Nike movements. We call this our identification and outreach program. Can you believe that most brands and their media agencies will only listen, if you mention 'high reach at low cost per contact'? We have convinced Nike, and many other leading brands that finding and engaging the 50000 most powerful share-determining opinion leaders on sports and sneakers can be at least as powerful for brand perception and loyalty as pushing TV Gross Rating Point (GRPs).

MM: What's an example of a Nike movement? IB: There are several. Nike + for runners, Nike Talk for sneaker freaks, Beat Gasoline for 'green and screenagers'. Nike understands the power of a facilitating and organic growing platform like Nike + . That is must also identify and connect powerful influencers to their brand.

MM: So, Nike creates spaces for interaction of sneaker freaks and other stakeholders in that conversation.

IB: Exactly. With customization in NikeID and many other programs, Nike understands the power of listening programs. Most companies don't have the mentality or DNA to open up and listen. They think shouting campaigns are the solution to convince consumers. And did you notice Adidas Originals on Facebook, with over 2 million loyal fans already? Or is having 2 million loyal fans and powerful sneezers also too niche and too low reach?

MM: So Nike came to you to engage you in an identifier program that identified the 50000 or so sneaker freaks around the world. You then used a variety of programs to identify them, and you invited the appropriate members of that group of 50000 or so influencers to
Nike programs, one of which would be Nike Talk, an online salon where people can talk and interact around a particular theme such as corporate or social responsibility.

IB: Yes. We sincerely believe in the power of platforms and communities to encourage participation, interactions, engagement and long-term loyalty. So brands connect to us for long-term social media marketing strategies and programs. We do not take a brand's money if it just wants a shouting banner on Facebook, or an intrusive and irrelevant pre-roll video commercial. We do explain why we say 'no', and show them much better alternatives like Dell Ideastorm, Starbucks Myidea, Jeep or Nike. MM: What's another example of a company with whom you've worked where you've used things like ViralTracker and social media monitoring?

IB: Our client Heineken International is very active in the global social space. In their social responsibility program KnowTheSigns, we have identified great new consumer insights with our brand-monitoring (buzz-tracking or conversation-tracking) program. The insights lead to how people behave when they've had one too many to drink. These insights were turned into five archetypes: a groper, a sleeper, a fighter and others. Next we looked at how the target agency $18-35$ years around the globe used social media like blogs, video portals, forums and social networks. We detected that social networks were used to plan a night out with friends. The same social networks were used to discuss the night out afterwards and to share pictures and videos with peers.

We blended all insights into a social marketing program with viral content, interactive videos, social networks widgets and much more. Via the widget social network users could show their friends how they behaved when drinking one too many. This widget ignited massive engagement, since over 5 million people participated and interacted. Stage one of this program won several awards and lifted Heineken's prompt awareness by 11 per cent, measured by MetrixLab. After 6 months the Heineken KnowTheSigns program is now switching to stage 2 .

(The full case study of KnowTheSigns stage 1 can be seen here: http://www.lacomunidad .co.uk/\#/cases/casesoverview.) 
MM: Do you have one more example that might highlight the notion of social media planning?

IB: Yes. Comscore, Nielsen and others only provide the top 10 social sites per country. You need many more 'social hot spots' to be able to do proper social media planning or to be able to find 50000 sneakers freaks, or other important niche groups of opinion leaders.

SocialMedia8 has a big pot of gold - it is our social media planning database, on which we have put a team for 2 years to get this done. In this database we gathered and ranked over 250000 social hot spots and influential opinion leaders divided by theme, topic, country and more criteria. So this is how we are able to connect Nike to 50000 leading sneaker freaks, LG to gadget-loving screenagers in 10 markets, Paramount to movie influencers, EA to powerful game leaders, Microsoft to tech leaders etc.

MM: How do you identify an influential site? What criteria do you use?

IB: There are many criteria to map and rank a social site as a 'hot spot' or a social influencer as share determining opinion leader. We blend collective ranking tools (Alexa, Technorati and eight others) with the ranking given by our social media specialists. I would like to tell you more details; however, this is our 'Coca Cola recipe'.

Just an example: Michael, if you ran a blog about sneakers with 100000 fans following your trends and opinion, you would qualify as sneaker freak and be part of our social media planning database and program. Whether we would connect you to Adidas or Nike would be up to us.

So far, there is no 'AdWords alike' auction yet, where brands can tell how much they are willing to pay to get connected to one important influencer or opinion leader. But I can tell you: the value and money paid for one influencer is much, much higher that the price payed for just one click on their Adword campaign in Google. Because an important influencer and his fan base can make or break a specific brand. So social can be much more important in the race for brand equity and brand ambassadors.

MM: So, you're looking for individuals who define themselves as mavens, experts, who develop opinions, recommendations, maybe even ratings and make sure that other people have access to those opinions or recommendations.

IB: Exactly. If you look at social influencers there are always 4-10 people around you in a specific field who you perceive as experts on movies, or mobile phones, or technology. And positive reviews and recommendations of peers you trust will influence your purchase decision. MM: So, most of us, especially those that are online on a regular basis, have a network of 4-10 experts to whom we go for very specific answers and recommendations.

Those 4-10 people are the influencers, correct? IB: As far as Nike goes: there are 50000 important sneaker freaks around the globe that influence 5000000 followers. It's like the song: follow the leader, follow the leader ....

So we create bottom-up strategies for brands. And make sure they listen to opinion leaders. Most brands do not want to listen to opinion leaders; that's not in their DNA. They would rather bribe the influencers, not understanding this is committing suicide, since opinion leaders will immediately use their power to destroy you. That's why SocialMedia8 is fully compliant with the Word of Mouth Marketing Association (WOMMA) code of conduct: be authentic, don't lie, bribe, cheat etc. This is where so many brands fail when they are hiring a social media marketing agency. Incredible, since a brand is the most valuable asset of any company! MM: This kind of tracks to the traditional metrics for social networks.

Out of a hundred users, you'll have one or two that are really creators of a movement. They start conversations. They nudge people along. Then there's another eight or nine people who join in the conversation as posters. They add comments. They don't necessarily generate it, but they respond. Eighty-five to ninety per cent of people are lurkers: they pay attention but they don't necessarily engage in any self-identified way in terms of posting comments.

IB: That's right. The 80-20 rule applies again. Nowadays, consumers want to be well informed and the Internet offers them these opportunities. And more important, the opinions of their peers are much more authentic, relevant and trustworthy than the over-promising ad campaigns where all brands 
shout the same: 'buy my product, it's better than the rest'.

MM: So social media planning is very much like traditional media planning.

With traditional media planning, a planner will be given a creative or marketing brief and they put together a mix of broadcast, ad, print, outdoor and so on, where they optimize and media-mix for maximum coverage of consideration, impressions, reach and so on, with respect to a particular demographic segment in a very specific geographic market.

Social media planning is similar, but it uses web analytics to identify the most influential people and how to engage them. Is that a good summary?

IB: Yes it is. With the big difference that a traditional strategic planner at an advertising agency has learned to find one big insight to create that one 'big idea'. Since they are campaigning, with top-down communications.

As a strategic social planner I have learned to look for more insights for a brand. I need to find several important insights to be able to create several smaller ideas that can lead into a 2-year platform, program, community or movement.

A relevant example to show you the difference: the success of the social marketing program by Barack Obama was not one insight and one big idea and campaign. There were many insights used as a foundation layer for a smart social marketing architecture. These insights were combined in a 4-year consumer connectivity program that organically changed with new insights.

The same is applicable for the programs of, for example, the Pope and Oprah: these are long-term social marketing programs, not just campaigns. And this is the exact problem of strategic planners from advertising agencies: they have always learned to push campaigns in a top-down way, through traditional channels.

A social strategic planner, however, must own the skills, experience and tactics to develop long-term listening and engagement programs that organically grow bottom-up. Trust me, it's a whole different ballgame.

MM: Another way of summarizing that: Social planning is about niche marketing. Niches that create multiple effects as a function of bottom-up word-of-mouth marketing.
IB: Exactly. And a well-planned social marketing program can grow bottom-up organically or fueled by a campaign, from a niche to a powerful mainstream movement. Take Nike + as an example: no screaming TV campaigns in the first stages. The program engages consumers and they help to improve the platform. Next a movement is created and that movement keeps growing organically, even when no campaign flights are launched.

But many brands launch the most lousy and irrelevant platforms and think they can grow them via TV campaigns. So basically these brands are inviting their targets to experience how much they understand their consumers' needs. Really amazing in the era where digital consumers have massively embraced platforms like Google, Nike+, Facebook and LastFM.

MM: Perhaps now would be a good time to shift into summarizing some of the major shifts that you've seen on the frontlines of this revolution?

IB: LaComunidad and SocialMedia8 call this era stage 2 of the revolution - the re-evolution. Stage 1 started around 1995 and in just 10 years the Internet changed how we consume media, how we communicate, and it shifted power to the people. This revolution disrupted business models, brands and communications in many ways. Ways most brands were not able to adapt to.

Consumers have taken control: the reviews, recommendations and opinions of peers are much more important in the buying or loyalty process than the messages of a brand. Look at Starbucks: their brand image switched from 'I love it' to 'ridiculous expensive coffee'. So Starbucks had to really open up to clients to refresh the brand again. And they did that with a smart social marketing program called MyIdea; it might have saved the brand ....

But unfortunately, only a few brands have the mentality and DNA to listen to their customers, consumers or fans. So I think customer-oriented and CRM-driven brands have a chance to do well in the re-evolution. Brands that don't will not all survive the re-evolution era - that is my opinion.

MM: So let us say that I have friends scattered around the world, and as a function of this much larger network of friends my ability to access very specific subject matter experts, or bounce ideas off people, is many times more 
significant. As a net result, any one of us is many times more intelligent, informed and insightful with regard to what's going on in the world.

IB: Much more intelligent and informed. The biggest shift might, however, be that consumers are not only in control, but have learned extremely fast how to use their power.

So even a powerful brand is not the owner of it's own brand anymore. Consumers know that most brand marketers are still in denial and do not recognize that control is just their illusion. If a brand, for example, launches lousy products or service, customers can now easily inform and warn their peers online. And both opinion leaders and lurkers are aware of this power.

So brands need a social media marketing agency much more in the re-evolution era. They are able to unleash the power of digital to transform business and brands. Ninety-five per cent of the advertising and media agencies will fail in this field. If a brand is indeed the most valuable asset, brand marketers should hire the right SWAT team for their rescue mission.

MM: This really goes back to a conversation that we've had on and off for maybe 8 years. I'd really like you to speak to not only share-determining market sectors as what that is, but how shifts in market shares have accelerated as a function of the much higher level of communication and interaction, vis-à-vis digital media telecommunications.

IB: Yes you are right. We have been talking about this for almost a decade. But the adoption curve for brands seems to very slow. There are some innovators and early adopters, but still too many laggards.

I have learned that social marketing is all about having the right mentality and DNA. I meet too many brands that do not want to interact or engage. They just aim for the quick bribe. And within the social space, this is a killing approach.

MM: And it also gets to another really key aspect of this engaged era.

It's not just enough that I make a complaint, and that I've had the experience that you've listened to me and understood; I'm not really fully engaged unless you take action on my earnest and well-intended recommendations.

So the idea then is how to succeed and thrive in the engaged era. It goes beyond just simply listening, but also having an effective, organizational change process in place so that we have ways of not only listening, but driving customer innovations, or customer insights, back into the operational aspects of the business.

That really closes the loop in terms of how companies innovate using constructive insights from customers.

IB: Yes exactly. A brand first needs to understand that the re-evolution needs new tactics, skills and insights. PR and brand marketers fool themselves with monthly PR clippings that only show published stories about the brand. Only with proper brand reputation-monitoring or buzz-tracking programs can brands really gain new insights and consumer opinions.

Next brands need to create processes, workflows and architectures that can embed new insights in a long-term program. Here we get back to strategic planning and tactics again. The engagement architecture, infrastructure and operational processes behind Obama's social marketing program were the foundation layers that built his success.

MM: So that brings us to another great point: engagement is not just a new buzzword, but it really represents a completely different set of operational capabilities, infrastructure, systems, processes and accountabilities for attracting and staying engaged with customers as their relationships evolve through various phases or stages of the overall life cycle. With the idea that I want to nudge a number of my customers to become advocates and stakeholders and ambassadors for our brand and value proposition in the market.

IB: Exactly. Why I keep mentioning the Obama case is straightforward but simple. Engagement is crucial, but very difficult. Why? Obama would have failed if he had just run a few campaigns. People acknowledged by the persistence of his program that he owned a different mentality and DNA - that he was authentic in his approach.

Obama's team embedded a suite of analytical tools in his engagement architecture. These tools enabled him to adapt to new insights time and time again.

Most of our clients track the impact and effectiveness of their social engagement programs. The tracking studies are performed by 
independent companies like Metrix Lab or TNS - so extremely trustworthy data and results These studies prove that engagement can increase prompt awareness, likeability and sales by $10-18$ per cent. So engagement a new buzzword - no it's a must-have ingredient. MM: This reminds me of another conversation I had with an innovator in social media monitoring. He shared with me the idea that agencies now create viral videos and they either post them on YouTube or they set up their own named social network, then invite influencers to see these things and have them vote, criticize and comment on them.

As soon as the video got vetted and validated by a social network, that became the event that triggered the full production of traditional broadcast and print promotional spots, reflecting the bottom-up support of advocates.

IB: This is why our ViralTracker is the most valuable strategic insight dashboard, not just a tracking technology. It tells us exactly what content, virals and commercials consumers do like, and what they do not like.

So due to ViralTracker, we can not only proof reach, response and impact of online content, it helps us to create better digital content strategies and more impactful content that is able to earn attention. And that is much more effective than pushing dull content by buying attention.

And if you create content, videos or webisodes that are embraced by consumers, the next step is that those consumers are willing to opt in for more. This is how great content and stories that connect create valuable relational databases of fans. Fans that will become brand ambassadors that spread the content to their peers again and again. And does this peer advocacy not seem like a smart, powerful and efficient way of doing marketing?

By this approach, brands can (i) earn attention and (ii) create their own media: large opt-in relational databases of loyal brand fans. Doesn't this sound much more exciting than buying attention through another flight for TV GRPs?

MM: Let's then look at and start talking about engagement strategies and agencies.

All of what we've discussed so far is both good news and bad news for traditional advertising agencies. It seems to me that you've been on the leading edge here of transforming agencies into another sort of organization.

IB: Indeed leading, but sometimes bleeding. Disruption and innovation are part of my DNA. So yes, leading, because I have repeatedly transformed my agencies and companies at a very early stage rather successfully - sometimes taking high risks.

Bleeding, because I have sold 75 per cent of my shares to market leader WPP. Don't get me wrong: due to our WPP membership we have brought our triple-play agency formula to many other markets rapidly. We would not have been able to do that so fast without the powerful WPP network. However, all large listed companies are risk averse. They sit, wait and buy the successful ones in the market. In this environment I'm not always able to explain and launch new innovative business models as fast as I could. Sometimes I feel like a racehorse behind a huge fence, if you understand what I mean.

I do feel that traditional agencies have been pretty lazy and have been neglecting to see the power of disruptive forces around us. The re-evolution has changed the world around us severely. I simply believe that nowadays agencies must be able to innovate; otherwise they will die a slow but painful death. And that goes for many other industries and companies as well.

For brands, I see lots of opportunities to invest in ecommerce and CRM programs. Having loyal customers that tell their friends to buy your products too makes economically much more sense than only keep spending budgets in shouting ad campaigns ....

MM: If I take what you've said to the next logical level, engagement agencies at some point cease being agencies and they become more permanent stakeholders in the marketing supply chain, and as a function of your ability to engage, interact and collaborate with the best customers of an organization that then should be informing upstream product innovation. Process innovation that is traditionally not part of marketing but more traditionally part of product management or research and development.

And as a function of that, to be able to bring the engaged customer into the ideation and research and development process, the engagement agency really becomes something much more than a just an agency. It's the 
connective tissue through the entire life cycle of awareness, consideration, trial, purchase, commitment, loyalty, advocacy and so on.

As you become the connective tissue you become a customer portfolio manager where you begin to manage a portfolio of customers. You start to drive more and more of your revenue from not just getting customers 'into the swimming pool', but managing them through the life cycle where those customers produce greater and greater value to the company. Does that scenario make sense to you?

IB: Yes sir!

Brands should look for engagement agencies that can help them to improve their marketing value chain. So hire agencies that will deliver more than 'lipstick on pig' campaigns. Agencies that can help to create loyal customers, fastergrowing and more profitable companies.

Agencies that can unleash the power of digital to transform businesses and brands.

MM: So as we move toward the conclusion of our interview today, how do you see the next three to 5 years rolling out?

IB: Our LaComunidad proposition has shifted long ago, from a creative digital agency into a digital marketing agency that also delivers ecommerce and CRM programs. We do already create consumer connectivity programs that increase brand equity and sales.

So we will stay focused on trends, consumer behavior and brands. And we will keep reinventing ourselves, no matter how often that will be necessary.

If I look at ViralTracker and SocialMedia8, I - forgive me - I do get a big smile on my face. Engagement agency SocialMedia8 is growing and expending much, much faster than LaComunidad. It's incredible to see how fast we have grown, even in the biggest recession ever.

Where other agencies are unfortunately firing people, we have been hiring 1 new FTE per month this year. Honestly, I have never experienced similar agency growth before. And I do not believe that social media marketing is hype. And if it is, we will re-invent ourselves again.

I sincerely do believe that eventually all brands will have a dedicated listening program. So hopefully my smile will become even bigger over the next few years, and social media marketing will become even more important.

MM: It seems to me, Igor, that one of the things that have permeated our conversation is the idea that it's more than just content; it's more than just 'lipstick on pigs', as you say.

In many cases, this next-generation agency or customer portfolio manager will in fact become a software-development organization - not where they are creating big enterprise applications, but where they're creating smaller software applications, widgets, services and so on.

So in many cases, you will create not only content, but you'll be creating services that somehow weave themselves into the fabric of the customer's experience of the brand, the value proposition, and the value-fulfillment process once I have bought the product and started to use it or consume the service. Can you speak to the notion of these agencies or portfolio managers where they're becoming more IT service-development and IT service-delivery organizations?

IB: Most advertising and media agencies have been profitable over the last decades. Unfortunately their shareholders and CEOs did not invest this money in innovation. So this is what they must change extremely fast, since the gap with innovative digital agencies is only becoming bigger,

As you said before, innovative brand engagement architectures, smart communication and messaging platforms, CRM-driven systems, technologies and infrastructures are now part of marketing.

So brands will need agencies that are able to help them to create dedicated CRM and database systems that can manage their processes of smart, personal and relevant two-way communications, micro-interactions and multiple engagements.

This includes smart digital content strategies, intelligent websites, platforms, communities and (social) networks, APIs and widgets. But also understand content management systems that deliver personal and relevant content and offers to the right customer persona.

Next the new agency also understands e-commerce, CRM and behavioral targeting, which will re-invent digital media planning as well. 
To learn how to run all this properly, traditional agencies will need another 10 years, or more. Most brands will need to implement these skills much sooner, so that's why I would like to place my bet on the digital marketing, CRM and social engagement agencies, as they have all embraced the Internet, similar technologies and systems already 10 years so. I hope you agree .... MM: This sounds like a great place to conclude. Igor, thank you so much for taking the time to share with us news from the frontlines. Before we conclude, is there any last comment, summary or otherwise that you'd like to leave us with today?

IB: Thank you very much for this opportunity. I think that we've touched on everything that is very important for the future. And I really hope that you and I will share more thoughts and ideas over the next coming 10 years. Campfire stories, as you like to call them ....

MM: Excellent. 